UDC 539.3

DOI: $10.32326 / 1814-9146-2019-81-2-249-259$

\title{
ON AN APPROACH TO THE DERIVATION OF CONSTITUTIVE EQUATIONS OF PHOTOCHROMIC MATERIALS
}

\author{
Eremeev V.A.
}

\author{
Gdansk Polytechnic University, Gdansk, Poland
}

Eremeyev.victor@gmail.com

Received by the Editor 2019/03/11

\begin{abstract}
The paper presents constitutive equations of deformed solids, the state parameters of which, apart from the displacement vector, include concentrations of photochromic compounds. Equilibrium equations are completed with chemical kinetic equations, which are a system of, in a general case, nonlinear ordinary differential equations or parabolic-type equations accounting for the diffusion of products of photochromic reactions. Coefficients of such equations (for example, quantum reaction yield, reaction rate) can be assumed to depend on the stressed state. Several versions of the dependence of coefficients of chemical kinetic equations on the stressed-strained state are introduced. Also, in the assumption of electrostatics, possible effects of electric fields are taken into account. In analogy with mechanics of semiconductors and conductors, related equations of state are proposed.

The introduced model of a coupled photo-electro-mechanical effect is a strongly nonlinear boundary-value problem, the equations of which contain a large number of material constants that must be determined experimentally. For conducting potential mechanical experiments, a simplified one-dimensional model is proposed, which is analogous to problems of tension-compression and bending in mechanics of bars and beams. In the framework thereof, solutions of related one-dimensional problems are constructed, which make it principally possible to define dimensionless complexes containing unknown material constants.
\end{abstract}

Keywords: constitutive relations, photochromic materials, concentrations, chemical kinetic equations, diffusion, stressed-strained state, electric fields, coupled photoelectro-mechanical effect, one-dimensional model.

\section{Introduction}

Nowadays, photochromic, as well as electrochromic and piezochromic materials are of considerable interest to manufacturers of various data storing and processing devices, electronics and nano-photonics, in particular, required for creating novel computer devices (molecular computers). Latest achievements in chemistry have made it possible to synthesize a wide range of photochromic compounds. The class of photochromic materials, as well as similar to them electrochromic and piezochromic compounds, are a fairly large group of substances, both organic (such as spirans, anthraquinones) and nonorganic (for example, some oxides). Some nanostructures, such as carbon nanopipes also manifest photochromic properties. 
Kinetics of photochromic reactions in dilute solutions is fairly well understood, whereas kinetic processes in a condensed state are less well known.

At the same time, construction of practical devices using photochromic compounds necessitates solving a number of problems of mechanics and material science. In particular, it is necessary to study the interrelation between characteristics of photochromic compounds and stressed-strained state, both determined by external loading and induced by the change of states of the molecules of a photochromic compound, to investigate the effect of stressedstrained state on aging characteristics of photochromic compounds, including the effect of the number of cycles of the direct-reverse photochromic reaction.

An important task in solving the above problems is developing a theory of defining relations of photochromic materials, accounting for the coupling of stress and strain fields with chemical reactions. The paper presents constitutive equations of deformed solids, the state parameters of which, apart from the displacement vector, include concentrations of photochromic compounds. Equilibrium equations are completed with chemical kinetic equations, which are a system of, in a general case, nonlinear ordinary differential equations or parabolic-type equations accounting for the diffusion of products of photochromic reactions. Coefficients of such equations (for example, quantum reaction yield, reaction rate) can be assumed to depend on the stressed state. Several versions of the dependence of coefficients of chemical kinetic equations on the stressed-strained state are introduced. Also, in the assumption of electrostatics, possible effects of electric fields are taken into account. In analogy with mechanics of semiconductors and conductors, related equations of state are proposed.

The introduced model of a coupled photo-electro-mechanical effect is a strongly nonlinear boundary-value problem, the equations of which contain a large number of material constants that must be determined experimentally. For conducting potential mechanical experiments, a simplified one-dimensional model is proposed, which is analogous to problems of tension-compression and bending in mechanics of bars and beams. In the framework thereof, solutions of related one-dimensional problems are constructed, which make it principally possible to define dimensionless complexes containing unknown material constants.

By now, a huge number of studies on photochromic, as well as piezochromic and electrochromic compounds have been published. Books [1-5] should be noted. Progress in chemistry of photochromic compounds is naturally connected with the advances of chemical science as a whole, as well as of photochemistry, photoconductance, etc. [6-9]. Most of those works are on chemical aspects, such as synthesis, properties, description of structures, characteristics of chemical reactions etc. (see, for example, [10-18]). Articles $[10,13,19-21]$ are dedicated to application of photochromic compounds. Thus, [10] considers use of photochromic materials in optical lenses. Dissertation [19], in particular, tackles the issues of using electrochromic materials in electronic devices (diodes etc.). Chemical kinetics of photochromic compounds was studied in [22-24]. It is to be noted that the works on chemical kinetics are of special interest in constructing a model of a photo-electro-mechanical effect, as these equations are a component part of such a model. In $[25,26]$, photo-degradation was studied. Despite the fact that chemical processes play a decisive role in describing photochromic compounds, the piezo-effect (the effect of pressure, strain) can also considerably affect the behavior of such compounds (see [21, 27-30] where experimental investigations of macroscopic specimens of photochromic 
compounds are also described). Magnetic properties of photochromes were the subject of study in [16], and electric ones in [17,31].

\section{Kinetics of photochromic transformations}

Equations of chemical kinetics describing photochromic reactions are a system of nonlinear differential equations of the following form [8, 22, 23, 32]:

$$
\frac{d c_{k}}{d t}=F_{k}\left(c_{1}, c_{2}, \ldots, c_{m} ; p, \theta, \lambda, I_{0}\right), \quad k=1, \ldots, m,
$$

where $c_{k}$ is concentration of substance, the right-hand sides of equation (1) depend, generally speaking, on temperature $\theta$, pressure $p$, wavelength of absorbed light $\lambda$, light flux intensity $I_{0}, t$ is time. The dependence of $F_{k}$ on concentration can be fairly complex and nonlinear. The material constants (quantum yield of the reaction, reaction rate etc.), included in (1), in a number of cases are well enough determined from experimental data [33], using the spectrophotometric method [9].

Equation set (1) adequately describes kinetics of chemical transformations under the conditions of ideal mixing, i.e., when concentration is the same at any point of the space. If this assumption does not hold, system (1) is transformed with the account of the diffusion and convective transfer processes [34-36]

$$
\frac{d c_{k}}{d t}=F_{k}\left(c_{1}, c_{2}, \ldots, c_{m} ; p, \theta, \lambda, I_{0}\right)+D_{k} \Delta c_{k}, \quad k=1, \ldots, m,
$$

where $D_{k}$ are diffusion coefficients, $d / d t=\partial / \partial t+\mathbf{v} \cdot \nabla$ is material derivative, $\mathbf{v}$ is rate vector.

In what follows, we shall confine ourselves with binary reactions of the form

$$
A \stackrel{\hbar v}{\longrightarrow} B, \quad B \longleftarrow \longleftarrow_{\hbar v} A
$$

representing the direct and reverse photoreactions for components $A$ and $B$, the concentrations of which will be designated by $c_{A}$ and $c_{B}$, respectively.

This will be exemplified by an equation of chemical kinetics for a photochromic reaction of the following form $[22,33]$ :

$$
\begin{gathered}
\frac{d c_{A}}{d t}=I_{0} F\left(\Phi_{B A} \varepsilon_{B} c_{B}-\Phi_{A B} \varepsilon_{A} c_{A}\right)+k_{A B} c_{A}, \quad F=\frac{1-10^{-A b s}}{A b s}, \\
A b s(\lambda)=\varepsilon_{A}(\lambda) c_{A}+\varepsilon_{B}(\lambda) c_{B} .
\end{gathered}
$$

Reaction rate is found using the Arrhenius formula $k_{A B}=k_{o} \exp \left(-E_{a} /(R \theta)\right)$, where $k_{o}$ is pre-exponential multiplier, $R$ is universal gas constant, $E_{a}$ is activation energy. $\operatorname{In}(4), F$ is photo-kinetic coefficient, $\Phi_{A B}$ and $\Phi_{B A}$ are quantum yields of the direct and reverse reactions, respectively, $\varepsilon_{A}$ and $\varepsilon_{B}$ are molar extinction coefficients depending on wavelength.

Considering equation (4) with the account of the specimen thickness, the change of the light flux due to absorption must be accounted for. To this end, value $I_{0}$ in (4) must be substituted for by light flux $I$ related with $I_{0}$ through Bouger's law

$$
I=I_{0} 10^{-\varepsilon c h},
$$

where $c$ is concentration of the light-absorbing substance, $h$ is thickness, $\varepsilon$ is molar extinction coefficient. In the case of two absorbents, Firordt's law can be used 


$$
I=I_{0} 10^{-\varepsilon_{A} c_{A} h-\varepsilon_{B} c_{B} h} .
$$

To account for the stressed-strained state effect on kinetics of phase transformations, it will be natural to assume that the coefficients of the chemical kinetic equations depend on stresses. Moreover, in the case of diffusion of a photochromic compound, not only diffusion transfer, proportional to the concentration gradient, must be accounted for, but also the transfer due to the pressure and electric field gradients:

$$
\frac{d c_{k}}{d t}=F_{k}\left(c_{1}, c_{2}, \ldots, c_{m} ; p, \theta, \lambda, I_{0} ; \sigma_{i j}\right)+D_{k} \Delta c_{k}+D_{k}^{\sigma} \Delta \sigma+D_{k}^{E} \Delta E, \quad \sigma=\sigma_{i i}, \quad k=1, \ldots, m .
$$

It will be assumed, in particular, that reaction rates are defined by a modified formula $k_{A B}=k_{o} \exp \left(\left(-E_{a}-\alpha \sigma_{i j} \sigma_{i j}\right) /(R \theta)\right)$, where $\alpha$ is dimensionless coefficient, and the other coefficients, in the assumption of the linear dependence on stresses or strains, can be represented by a sum of two summands of the following form:

$$
I=I^{o}+\sigma I^{\sigma},
$$

where $I^{o}$ is value of a quantity for the zero stress level, and $\sigma I^{\sigma}$ is correction. For a light flux, such a representation is obtained directly, taking into consideration the fact that the thickness of the layer on which the flux is defined changes linearly during the deformation of the body. If diffusion transfer processes are neglected, then, taking into account the high rate of transformations as compared with the deformation processes, it can be assumed that concentrations of a photochromic compound in various forms (A and B) can be found from the conditions of chemical equilibrium, i.e., as stationary solutions of equations

$$
F_{k}\left(c_{1}, c_{2}, \ldots, c_{m} ; p, \theta, \lambda, I_{0} ; \sigma_{i j}\right)=0, \quad k=1, \ldots, m .
$$

In this case, naturally, equilibrium concentrations are affected by the stressed-strained state, and incident light flux $I_{0}$ is a controlling parameter altering the properties of the medium.

It is to be noted that, for multiple cycles of photochromic transformations, the photodegradation phenomenon $[25,26]$ is observed, which is manifested in the fact that, alongside with direct and reverse reactions (3), other reactions take place, which bring the reacting substances out of the photochromic transformation process. The concentration of such substances will be designated by $c_{c}$. If the coefficient of photo-degradation during one cycle of 'the direct-reverse reaction' is designated by $f_{d}$, then, after $N$ cycles, the total concentration of the photochromic compounds can be found using the following formula [25]:

$$
\left.\left(c_{A}+c_{B}\right)\right|_{N}=\left.\left(c_{A}+c_{B}\right)\right|_{0}\left(1-f_{d}\right)^{N} .
$$

Thus, the concentration of sub-products $c_{c}$ can be determined as a function of number of cycles $N$.

As a result of the assumptions made, it is postulated that concentrations of a photochromic compound can be determined using the following phenomenological relations:

$$
\begin{array}{ll}
c_{A}=\widetilde{c}_{A}\left(I_{0}, \sigma\right)\left(1-f_{d}\right)^{N}, & \widetilde{c}_{A}\left(I_{0}, \sigma\right)=c_{A}\left(I_{0}\right)+B_{A} \sigma, \\
c_{B}=\widetilde{c}_{B}\left(I_{0}, \sigma\right)\left(1-f_{d}\right)^{N}, & \widetilde{c}_{B}\left(I_{0}, \sigma\right)=c_{B}\left(I_{0}\right)+B_{B} \sigma,
\end{array}
$$

where $B_{A}$ and $B_{B}$ are piezocoefficients $\left(\widetilde{c}_{A}+\widetilde{c}_{B}=1\right)$, and for $\widetilde{c}_{A}$ the following relation is used. 


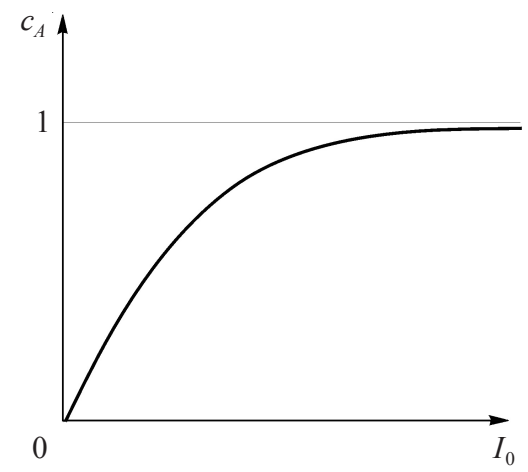

Fig. 1

It should be noted that kinetics of photochemical reactions may differ for diluted solutions (both liquid and solid) of photochromic compounds and for photochromic compounds in a condensed state. For instance, absorption of a quantum of light by a molecule in a condensed state may fail to result in its transformation because of the interaction between the molecules of the photochromic compound. For solid solutions, the orientation of the molecules of the photochromic compound and the resulting anisotropy of the optical properties can be essential. A photoreaction can also be affected by photoluminescence of the substance surrounding the photochromic material of the substance.

\section{The one-dimensional model}

Consider a spatially one-dimensional continuum model consisting of a photochromic material. As rates of chemical reactions are much higher than characteristic times of deformation processes, it is assumed that concentration of the substances taking part in photoreactions do not depend on time and at each point of the body are determined from the chemical equilibrium conditions for the given temperature, pressure and other parameters.

Without going into the details of chemical kinetics, concentrations $c_{A}$ and $c_{B}$, as well as number of cycles $N$ of 'the direct-reverse photoreaction' will be introduced as variables "in charge" of photochromic reactions in the continuum.

Equations of state will be written in the following form:

$$
\sigma=c u^{\prime}-e E, \quad D=e u^{\prime}+\varepsilon E, \quad j=q\left(n_{0}+f n\right) \mu E+q f d n^{\prime} .
$$

In (5), $\sigma$ is stress, $u$ is displacement, a stroke designates a derivative along space coordinate $x, E$ is intensity of electric field, $D$ is induction, $j$ is current, $c, e, \varepsilon$ are elasticity modulus, piezo-modulus and dielectric permeability of the medium, respectively, $q$ is electronic charge, $n_{0}+n$ is concentration of electrons (free charge carriers), $n$ is concentration of electrons in the absence of mechanical strains, $\mu$ is mobility, $f$ is trapping factor, $d$ is diffusion coefficient of the carriers. Equations of state (5) are a special case of the equations of state of elastic semiconductors [32,33, 37, 38]. Equation (5) does not account for the photo-effect, i.e., the appearance of free carriers under the effect of radiation [7].

Equations of motion and Maxwell's equations, in the case of electrostatics in a onedimensional case, take the following form 


$$
\rho \ddot{u}=\sigma^{\prime}, \quad D^{\prime}=-q\left(n_{0}+n\right), \quad j^{\prime}=q \dot{n},
$$

where $\rho$ is density of the photochromic compound.

It is to be noted that the material constants ( $c, e, \varepsilon$ and others) entering the equation, generally speaking, depend on the chemical composition of the medium, i.e., concentrations $c_{A}$ and $c_{B}$, which, in their turn, are assumed to depend on stress field $\sigma$ according to the latter formulas of the previous section.

Consider a stationary solution of problem (5), (6) under the conditions of a constant homogeneous electric field. It is then evident that

$$
\sigma=\sigma_{0}=\text { const }, \quad j=j_{0}=\text { const }, \quad n_{0}+n=0 .
$$

Thus, based on a static experiment, it is, in principle, possible to measure some of the constants, for example, the elasticity modulus, depending on the presence of a light flux and its intensity, as well as the number of cycles of photochromic transformations, or determining displacements as a function of the light flux. In particular, as the absorption of light is inhomogeneous through the thickness, bending of the photochromic compound plate under the conditions of radiation is possible.

Nevertheless, studying oscillations or wave propagation in such a one-dimensional medium, for instance, in analogy with studying sound wave propagation in semiconductors [39], appears to be more promising, though more difficult.

\section{Conclusion}

The paper presents equations of chemical kinetics for photochromic compounds and proposes resolving equations of photo-electro-mechanical effect in a spatially onedimensional case.

In a three-dimensional case, the formulation can be confined to the case of a diluted solid solution of a photochromic compound in a solid matrix. To this end, it appears sufficient, in the first approximation, to use equations of thermal diffusion [40], completed with equations of chemical kinetics in form of (1) or (2). At the same time, it is well known that dynamic processes in solids are accompanied by the interaction of sound and light waves (acoustic-optics) [39] and the dependence of the refraction coefficient on stresses in the body (the piezo-optic effect) [41, 42]. In optoelectronics, other nonlinear interactions also appear to be essential [42]. Besides, unavoidable presence of various kinds of defects (dislocations, impurities) and anisotropy of the properties of the body containing a photochromic compound can also substantially complicate the processes.

For a photochromic compound distributed over the surface of a body, all kinds of surface phenomena can play an important part [43,44].

The above effects also appear, to this or that degree, in a one-dimensional case. Naturally, determining the most important factors affecting coupled processes of photochemistry and stressed state must be based on related experiments.

\section{References}

1. Organic Photocromic and Thermochromic Compounds. Vol. I. Main Photochromic Compound. Eds. J.C. Crano, R.J. Guiglielmettii. N.Y. Plenum Press. 1999. 369 p.

2. Organic Photocromic and Thermochromic Compounds. Vol. II. Physicochemical Studies, Biological Applications, and Thermochromism. Eds. J.C. Crano, R.J. Guiglielmettii. N.Y. Plenum Press. 1999. 466 p. 
3. Techniques in Chemistry. Vol. III. Photochromism. Ed. G.Y. Brown. N.Y. John Willey\&Sons Inc. $1971.853 \mathrm{p}$.

4. Photochromism: Moleculas and Systems. Eds. Y. Durr, H. Bouas-Laurent. Amsterdam. Elsevier. 1990. 1218 p.

5. Vvedenie v fotokhimiyu organicheskikh soedineniy. Pod red. G.O. Becker [Introduction to the Photochemistry of Organic Compounds. Ed. G.O. Becker]. Leningrad. Khimiya Publ. 1976. 384 p. (In Russian).

6. Calvert J.G., Pitts Jr. J.N. Photochemistry. London. John Wiley\&Sons Inc. 1966. 782 p.

7. Rose A. Concepts in Photoconductivity and Allied Problems. N.Y. London. John Wiley \&Sons. 1963. $168 \mathrm{p}$.

8. Fizicheskaya khimiya [Physical Chemistry]. Ed. B.P. Nikolskiy. Leningrad. Khimiya Publ. 1987. 880 p. (In Russian).

9. Bershteyn I.Ya., Kaminskiy Yu.L. Spektrofotometricheskiy analiz v organicheskoy khimii. [Spectrophotometric Analysis in Organic Chemistry]. Leningrad. Khimiya Publ. 1975. 232 p. (In Russian).

10. Crano J.C., Flood T., Knowles D., Kumar A., Van Gemert B. Photochromic compounds: Chemistry and application in ophthalmic lenses. Pure App. Chem. 1996. Vol. 68. No 7. P. 1395-1398.

11. Ivakhnenko T.E., Makarova N.I., Ivakhnenko E.P., Minkin V.I., Knyazhansky M.I. Photoinitiated azo-hydrazo tautomerizm of 1-p- toluenesulphonylazo-2,4,6,8-tetrakis (tertbutyl)phenoxazine. Int. J. Photoenergy. 1999. Vol. 1. Iss. 3. P. 161-164. DOI: 10.1155/ S1110662X99000288.

12. Voloshin N.A., Chernyshev A.V., Metelitsa A.V., Besugliy S.O., Voloshina E.N., Sadimenko L.P., Minkin V.I. Photochromic spiro [indoline-pyridobenzopyrans]: fluorescent metal-ion sensors. ARKIVOC. 2004. Vol. 2004. Iss. 11. P. 16-24.

13. Sliwa M., Létard S., Malfant I., Nierlich M., Lacroix P.G., Asahi T., Masuhara H., Yu P., Nakatani K. Design, synthesis, structural and nonlinear optical properties of photochromic crystals: toward reversible molecular switches michel sliwa. Chem. Mater. 2005. Vol. 17. No 18. P. 4727-4735.

14. Evans L., Collins G.E., Shaffer R.E., Michelet V., Winkler J.D. Selective metals determination with a photoreversible spirobenzopyran. Anal. Chem. 1999. Vol. 71. P. 5322-5327.

15. Linert W., Fukuda Y., Camard A. Chromotropism of coordination compounds and its applications in solution. Coord. Chem. Rev. 2001. Vol. 218. P. 113-152.

16. Matsuda K., Irie M. Diarylethene as a photoswitching unit. J. Photoch. Photobio. C. 2004. Vol. 5. P. 169-182.

17. Kazanskii S.A., Rumyantsev D.S., Ryskin A.I. Dielectric response of semiconducting and photochromic CdF2 on microwaves. Physica B: Condensed Matter. 2001. Vol. 308. P. 1038-1041.

18. Avellaneda C.O., Bulhoes L.O.S. Photochromic properties of WO3 and WO3: X (X=Ti, $\mathrm{Nb}$, Ta and Zr) thin films. Solid State Ionics. 2003. Vol. 165. P. 117-121.

19. Leger J.J.M. Electrochemical doping and the optical properties of light-emitting polymer materials and devices. ProQuest Dissertations and Theses Thesis (Ph.D). 2005. Vol. 66-10. Section B. $155 \mathrm{p}$.

20. Yang G., Gong J., Yang R., Guo H., Wang Y., Liu B., Dong S. Modification of electrode surface through electrospinning followed by self-assembly multilayer of polyoxometalate and its photochromic. Electrochem. Commun. 2006. Vol. 8. P. 790-796.

21. Hu H., Hechavarrý L., Campos J. Optical and electrical responses of polymeric electrochromic devices: effect of polyacid incorporation in polyaniline film. Solid State Ionics. 2003. Vol. 161. P. 165-172.

22. Favaro G., Romani1 A., Becker R.S. Photochromic behavior of 2,2-Spiro-adamantylidene2H naphtha [1,2-b]pyran: A new thermoreversible and photoreversible photochromic system. Photochem. Photobiol. 2000. Vol. 72. Iss. 5. P. 632-638.

23. Janus K., Koshets I.A., Sworakowski J., Nešpůrek S. An approximate non-isothermal method to study kinetic processes controlled by a distribution of rate constants: the case of a photochromic azobenzene derivative dissolved in a polymer matrix. J. Mater. Chem. 2002. Vol. 12. P. $1657-1663$.

24. Favaro G., Levi D., Ortica F., Samat A., Guglielmetti R., Mazzucato U. Photokinetic behaviour of bi-photochromic supramolecular systems. Part 3. Compounds with chromene and 
spirooxazine units linked through ethane, ester and acetylene bridges. J. Photochem. Photobio. A. 2002. Vol. 149. P. 91-100.

25. Bouas-Laurent H., Durr H. Organic photochromism (IUPAC Technical Report). Pure Appl. Chem. 2001. Vol. 73. No 4. P. 639-665.

26. Koppetsch K.J. Photodegradation of organic photochromic dyes incorporated in ormosil matrices. A Thesis Submitted to the Faculty of the Worcester Polytechnic Institute for the Degree of Master of Science in Chemistry. Worcester. USA. 2000. 52 p.

27. Hua X.B., Wang J.Y., Zhang H.J., Jiang H.D., Liu H., Mu X.D., Ding Y.J. Dependence of photochromic damage on polarization in KTiOPO4 crystals. J. Cryst. Growth. 2003. Vol. 247. P. 137-140.

28. Grey J.K., Butler Ia.S. Effects of high external pressures on the electronic spectra of coordination compounds. Coordin. Chem. Rev. 2001. Vol. 219. P. 713-759.

29. Kullman L., Azens A., Granqvist C.G. Electrochromism and photochromism of reactively DC magnetron sputtered MoTi oxide films. Sol. Energ. Mat. Sol. C. 2000. Vol. 6. P. 189-196.

30. Gong J., Li X.-D., Shao C.-L., Ding B., Lee D.-R., Kim H.-Y. Photochromic and thermal properties of poly(vinyl alcohol)/H6P2W18O62 hybrid membranes. Mater. Chem. Phys. 2003. Vol. 79. P. 87-93.

31. Kawai T., Nakashima Y., Kunitake T., Irie M. Photon-mode modulation of fluorescence and electrical current with a photochromic conducting polymer. Curr. Appl. Phys. 2005. Vol. 5. P. 139-142.

32. Maugin G. Continuum Mechanics of Electromagnetic Solids. Amsterdam. Elsevier Science Ltd. 1988.598 p.

33. Metelitsa V., Lokshin V., Micheau J.C., Samat A., Guglielmetti R., Minkin V.I. Photochromism and solvatochromism of push-pull or pull-push spiroindolinenaphthoxazinesy. $J$. Phys. Chem. 2002. Vol. 4. P. 4340-4345.

34. Prigozhin I., Defey R. Khimicheskaya termodinamika [Chemical Thermodynamics]. Novosibirsk. Nauka Publ. 1966. 502 p. (In Russian).

35. Zhabotinskiy A.M. Kontsentratsionnye avtokolebaniya [Concentration Self Oscillations]. Moscow. Nauka Publ. 1974. 179 p. (In Russian).

36. Metrikin V.S., Igumnov L.A., Zaitsev M.V., Boev A.V. Dynamics of a vibration system, taking into account the hereditary type friction and the mobility of a vibration limiter. MATEC Web of Conferences. 2018. Vol. 226. DOI: 10.1051/matecconf/201822603022.

37. Parton V.Z., Kudryavtsev B.A. Elektromagnitouprugost pyezoelektricheskikh i elektroprovodnykh tel [Electromagnetic Resilience of Piezoelectric and Electrically Conductive Bodies]. Moscow. Nauka Publ. 1988. 472 p. (In Russian).

38. Novatskiy V. Elektromagnitnye effekty v tverdykh telakh [Electromagnetic Effects in Solids]. Moscow. Mir Publ. 1986. 160 p. (In Russian).

39. Krasilnikov V.A., Krylov V.V. Vvedenie v fizicheskuyu akustiku [Introduction to Physical Acoustics]. Moscow. Nauka Publ. 1984. 400 p. (In Russian).

40. Podstrigach Ya.S., Povstenko Yu.Z. Vvedenie v mekhaniku poverkhnostnykh yavleniy $v$ deformiruemykh tverdykh telakh [Introduction to the Mechanics of Surface Phenomena in Deformable Solids]. Kiev. Naukova dumka Publ. 1985. 200 p. (In Russian).

41. Kittel Ch. Introduction to Solid State Physics. John Wiley\&Sons Inc. 1975. 675 p.

42. Rozenberg E., Vinter V. Optoelektronika [Optoelectronics]. Moscow. Tehnosfera Publ. 2004. 592 p. (In Russian).

43. Rusanov A.I. Surface thermodynamics revisited. Surf. Sci. Rep. 2005. Vol. 58. P. 111-239.

44. Adamson A.W., Gast A.P. Physical Chemistry of Surfaces. N.Y. John Wiley\&Sons Inc. 1997. $784 \mathrm{p}$.

Список литературь

1. Organic Photocromic and Thermochromic Compounds. Vol. I. Main Photochromic Compound. Eds. J.C. Crano, R.J. Guiglielmettii. N.Y. Plenum Press. 1999. 369 p.

2. Organic Photocromic and Thermochromic Compounds. Vol. II. Physicochemical Studies, Biological Applications, and Thermochromism. Eds. J.C. Crano, R.J. Guiglielmettii. N.Y. Plenum Press. 1999. 466 p. 
3. Techniques in Chemistry. Vol. III. Photochromism. Ed. G.Y. Brown. N.Y. John Willey\&Sons Inc. $1971.853 \mathrm{p}$.

4. Photochromism: Moleculas and Systems. Eds. Y. Durr, H. Bouas-Laurent. Amsterdam. Elsevier. 1990. 1218 p.

5. Введение в фотохимию органических соединений. Под ред. Г.О. Беккер. Л.: Химия, $1976 \mathrm{c}$.

6. Calvert J.G., Pitts Jr. J.N. Photochemistry. London: John Wiley\&Sons Inc., 1966. 782 p.

7. Rose A. Concepts in Photoconductivity and Allied Problems. N.Y.-London: John Wiley \&Sons, 1963. 168 p.

8. Физическая химия. Под ред. Б.П. Никольского. Л.: Химия, 1987. 880 с.

9. Берштейн И.Я., Каминский Ю.Л. Спектрофотометрический анализ в органической химии. Л.: Химия, 1975. 232 с.

10. Crano J.C., Flood T., Knowles D., Kumar A., Van Gemert B. Photochromic compounds: Chemistry and application in ophthalmic lenses. Pure and Applied Chemistry. 1996. Vol. 68. No 7. P. $1395-1398$.

11. Ivakhnenko T.E., Makarova N.I., Ivakhnenko E.P., Minkin V.I., Knyazhansky M.I. Photoinitiated azo-hydrazo tautomerizm of 1-p- toluenesulphonylazo-2,4,6,8-tetrakis (tertbutyl)phenoxazine. International Journal of Photoenergy. 1999. Vol. 1. Iss. 3. DOI: 10.1155/ S1110662X99000288.

12. Voloshin N.A., Chernyshev A.V., Metelitsa A.V., Besugliy S.O., Voloshina E.N., Sadimenko L.P., Minkin V.I. Photochromic spiro [indoline-pyridobenzopyrans]: fluorescent metal-ion sensors. ARKIVOC. 2004. Vol. 2004. Iss. 11. P. 16-24.

13. Sliwa M., Létard S., Malfant I., Nierlich M., Lacroix P.G., Asahi T., Masuhara H., Yu P., Nakatani K. Design, synthesis, structural and nonlinear optical properties of photochromic crystals: toward reversible molecular switches michel sliwa. Chemistry of Materials. 2005. Vol. 17. No 18. P. 4727-4735.

14. Evans L., Collins G.E., Shaffer R.E., Michelet V., Winkler J.D. Selective metals determination with a photoreversible spirobenzopyran. Analytical Chemistry. 1999. Vol. 71. P. 5322-5327.

15. Linert W., Fukuda Y., Camard A. Chromotropism of coordination compounds and its applications in solution. Coordination Chemistry Reviews. 2001. Vol. 218. P. 113-152.

16. Matsuda K., Irie M. Diarylethene as a photoswitching unit. Journal of Photochemistry and Photobiology C: Photochemistry Reviews. 2004. Vol. 5. P. 169-182.

17. Kazanskii S.A., Rumyantsev D.S., Ryskin A.I. Dielectric response of semiconducting and photochromic CdF2 on microwaves. Physica B. Condensed Matter. 2001. Vol. 308. P. 1038-1041.

18. Avellaneda C.O., Bulhoes L.O.S. Photochromic properties of WO3 and WO3: X (X=Ti, $\mathrm{Nb}$, Ta and Zr) thin films. Solid State Ionics. 2003. Vol. 165. P. 117-121.

19. Leger J.J.M. Electrochemical doping and the optical properties of light-emitting polymer materials and devices. ProQuest Dissertations and Theses Thesis (Ph.D). 2005. Vol. 66-10. Section B. 155 p.

20. Yang G., Gong J., Yang R., Guo H., Wang Y., Liu B., Dong S. Modification of electrode surface through electrospinning followed by self-assembly multilayer of polyoxometalate and its photochromic. Electrochemistry Communications. 2006. Vol. 8. P. 790-796.

21. Hu H., Hechavarrý L., Campos J. Optical and electrical responses of polymeric electrochromic devices: effect of polyacid incorporation in polyaniline film. Solid State Ionics. 2003. Vol. 161. P. 165-172.

22. Favaro G., Romani1 A., Becker R.S. Photochromic behavior of 2,2-Spiro-adamantylidene$2 \mathrm{H}$ naphtha [1,2-b]pyran: A new thermoreversible and photoreversible photochromic system. Photochemistry and Photobiology. 2000. Vol. 72. Iss. 5. P. 632-638.

23. Janus K., Koshets I. A., Sworakowski J., Nešpůrek S. An approximate non-isothermal method to study kinetic processes controlled by a distribution of rate constants: the case of a photochromic azobenzene derivative dissolved in a polymer matrix. Journal of Materials Chemistry. 2002. Vol. 12. P. 1657-1663.

24. Favaro G., Levi D., Ortica F., Samat A., Guglielmetti R., Mazzucato U. Photokinetic behaviour of bi-photochromic supramolecular systems. Part 3. Compounds with chromene and 
spirooxazine units linked through ethane, ester and acetylene bridges. Journal of Photochemistry and Photobiology A: Chemistry. 2002. Vol. 149. P. 91-100.

25. Bouas-Laurent H., Durr H. Organic photochromism (IUPAC Technical Report). Pure and Applied Chemistry. 2001. Vol. 73. No 4. P. 639-665.

26. Koppetsch K. J. Photodegradation of organic photochromic dyes incorporated in ormosil matrices. A Thesis Submitted to the Faculty of the Worcester Polytechnic Institute for the Degree of Master of Science in Chemistry. Worcester. USA. 2000. 52 p.

27. Hua X.B., Wang J.Y., Zhang H.J., Jiang H.D., Liu H., Mu X.D., Ding Y.J. Dependence of photochromic damage on polarization in KTiOPO4 crystals. Journal of Crystal Growth. 2003. Vol. 247. P. 137-140.

28. Grey J.K., Butler Ia.S. Effects of high external pressures on the electronic spectra of coordination compounds. Coordination Chemistry Reviews. 2001. Vol. 219. P. 713-759.

29. Kullman L., Azens A., Granqvist C.G. Electrochromism and photochromism of reactively DC magnetron sputtered MoTi oxide films. Solar Energy Materials \& Solar Cells. 2000. Vol. 6. P. $189-196$.

30. Gong J., Li X.-D., Shao C.-L., Ding B., Lee D.-R., Kim H.-Y. Photochromic and thermal properties of poly(vinyl alcohol)/H6P2W18O62 hybrid membranes. Materials Chemistry and Physics. 2003. Vol. 79. P. 87-93.

31. Kawai T., Nakashima Y., Kunitake T., Irie M. Photon-mode modulation of fluorescence and electrical current with a photochromic conducting polymer. Current Applied Physics. 2005. Vol. 5. P. 139-142.

32. Maugin G. Continuum Mechanics of Electromagnetic Solids. Amsterdam. Elsevier Science Ltd. 1988.598 p.

33. Metelitsa V., Lokshin V., Micheau J. C., Samat A., Guglielmetti R., Minkin V.I. Photochromism and solvatochromism of push-pull or pull-push spiroindolinenaphthoxazinesy. Journal of Physical Chemistry A. 2002. Vol. 4. P. 4340-4345. $502 \mathrm{c}$.

34. Пригожин И., Дефэй Р. Химическая термодинамика. Новосибирск: Наука, 1966.

35. Жаботинский А.М. Концеентрациионные автоколебания. М.: Наука, 179 с.

36. Metrikin V.S., Igumnov L.A., Zaitsev M.V., Boev A.V. Dynamics of a vibration system, taking into account the hereditary type friction and the mobility of a vibration limiter. MATEC Web of Conferences. 2018. Vol. 226. DOI: 10.1051/matecconf/201822603022.

37. Партон В.З., Кудрявцев Б.А. Электромагнитоупругость пьезоэлектрических и электропроводных тел. М.: Наука, 1986. 472 с.

38. Новацкий В. Электромагнитные эффекты в твердых телах. М.: Мир, 1986. 160 с.

39. Красильников В.А., Крылов В.В. Введение в физическую акустику. М.: Наука, 1984. $400 \mathrm{c}$.

40. Подстригач Я.С., Повстенко Ю.З. Введение в механику поверхностных явлений в деформируемых твердых телах. Киев: Наукова думка, 1985. 200 с.

41. Kittel Ch. Introduction to Solid State Physics. John Wiley\&Sons Inc., 1975. 675 p.

42. Розенберг Е., Винтер В. Оптоэлектроника. М.: Техносфера, 2004. 592 с.

43. Rusanov A.I. Surface thermodynamics revisited. Surface Science Reports. 2005. Vol. 58. P. 111-239.

44. Adamson A.W., Gast A.P. Physical Chemistry of Surfaces. N.Y.: John Wiley\&Sons Inc., 1997. $784 \mathrm{p}$. 


\title{
ОБ ОДНОМ ПОДХОДЕ К ПОСТРОЕНИЮ УРАВНЕНИЙ СОСТОЯНИЯ ФОТОХРОМНЫХ МАТЕРИАЛОВ
}

\author{
Еремеев B.A.
}

Гданьский политехнический университет, Гданьск, Польша

Предложены уравнения состояний деформируемой твердой среды, параметрами состояния которой наряду с вектором перемещений являются концентрации фотохромных соединений. Уравнения равновесия дополняются уравнениями химической кинетики, которые представляют собой систему в общем случае нелинейных обыкновенных дифференциальных уравнений или уравнений параболического типа при учете диффузии продуктов фотохромных реакций. Коэффициенты этих уравнений (например, квантовый выход реакции, скорости реакции) могут предполагаться зависящими от напряженного состояния. Предложены различные варианты зависимости коэффициентов уравнений химической кинетики от напряженно-деформированного состояния. Также в приближении электростатики учтено возможное воздействие электрического поля. По аналогии с механикой упругих полупроводников и проводников предложены соответствующие уравнения состояния.

Предложенная модель связанного фото-электро-механического эффекта представляет собой сильно нелинейную краевую задачу, уравнения которой содержат большое количество материальных постоянных, подлежащих определению экспериментально. Для постановки возможных механических экспериментов предложена упрощенная одномерная модель, аналогичная задачам растяжения-сжатия и изгиба в механике стержней и балок. В ее рамках построены решения соответствующих одномерных задач, которые дают принципиальную возможность определения безразмерных комплексов, содержащих неизвестные материальные постоянные.

Ключевые слова: уравнения состояния, фотохромные материалы, концентрация, уравнения химической кинетики, диффузия, напряженно-деформированное состояние, электрическое поле, связанный фото-электро-механический эффект, одномерная модель. 